\title{
Different Approaches to the Objects of Phraseology in Linguistics
}

\author{
Kamala Vasif Guliyeva ${ }^{1}$ \\ ${ }^{1}$ Department of English Grammar, Azerbaijan University of Languages, Baku, Azerbaijan \\ Correspondences: Kamala Vasif Guliyeva, Department of English Grammar, Azerbaijan University of Languages, \\ Baku, Azerbaijan. E-mail: kamala_guliyeva@yahoo.com
}

Received: June 15, 2016 Accepted: June 29, 2016 Online Published: July 13, 2016

doi:10.5539/ijel.v6n4p104 URL: http://dx.doi.org/10.5539/ijel.v6n4p104

\begin{abstract}
The article deals with phraseology and its object. Phraseology is known to be one of the difficult, debatable and interesting parts of linguistics. It appeared in the middle of the 19th century as a science, and was firstly dealt widely with by the scholars of the post-Soviet country. The early researchers of phraseology were Russian scholars and linguists such as Abakumov, Reformatski, Arnold, Bulakhovski, Ojegov, Amosova, Vinogradov, etc. Though being mostly investigated by Russian specialist, phraseology has been the target of the research of the following Azerbaijan linguists-Seyidov, Shiraliyev, Bayramov, Rustamov, Huseynzade, \& Veliyeva. The subject matter of phraseology was very interesting to most linguists, however, it was impossible to originate a single theory on phraseology.

In this article we have touched upon the main terms used in phraseology, such as, set expression, idiom, set phrase, fixed word-groups, word-equivalent, phraseological unit, etc. These terms are defined differently by some scholars. Connotational and denotational meanings of phraseological units are described discussed here. Besides, three approaches to the study of phraseological units (semantic approach, functional approach, contextual approach) are discussed in details.
\end{abstract}

Keywords: phraseological units, linguistics, phraseology, phraseological combination, phraseological unit, idiom

\section{Introduction}

One of the debatable matters of linguistics is phraseology and this linguistic phenomenon doesn't lose its actuality, vice-versa, it being used in any language more and more gains new shades (Akhmanova, 1972). The investigation of the sources concerning phraseology shows that this problem hasn't been completely solved from theoretical and practical points of view. We can assuredly state that phraseological units (combinations, idioms) are used widely in all languages.

\section{Scope of the Study}

Phraseology, which studies phraseological units of the language, as the branch of Linguistics appeared in the 1940s. The object of Phraseology is phraseological units, their nature, and the way they function in speech. However, there is a problem of terminology in linguistics connected with phraseology, since there are the following terms which are used in this branch of linguistics:

- set expression or word-equivalent;

- idiom;

- set phrase;

- fixed word-groups;

- phraseological combinations;

- phraseological fusions;

- phraseological unit.

The above-mentioned terms are used by scholars differently, and sometimes they express one and the same notion. In this article we are going to discuss what is included in phraseology, and to try to determine the peculiarities of the above given terms used in phraseology. 


\section{Research Methodology}

All the investigations are held with the help of investigation methods, and all the methods should be determined and chosen in connection with the topic investigated. The appropriate choice of methods guarantees the objective results of the investigation.

In the investigation process of the given topic we have used the following methods: synchronic method, descriptive method, observation method, linguistic analysis method.

\section{Viewpoints on Phraseology}

\subsection{Differentiation of the Phraseological Terms by Russian Scholars}

Set expression is "a unit which consists of two or more stressed words, which are semantically full (undivided), and according to structure and word composition is unchanged or stable". This definition belongs to Shanskiy (Shanskiy, 1957).

Let's look through the above mentioned terms one by one.

Set phrase "implies that the basic criterion of differentiation is stability of the lexical components and grammatical structure of word-groups", which is Arnold's viewpoint (Arnold, 1959).

Word-equivalent "stresses semantic and functional inseparability of certain word-groups, their aptness to function in speech as single words", which is Smirnitstky's opinon (Smirnitski, 1998).

Phraseological unit is "the most acceptable terms created and used by Russian linguists". Phraseological units are not always stable like set expressions, they do not always become equivalent to one word (like word-equivalents) and not always idiomatic (like idioms); they may be only partially motivated. Phraseological units are non-motivated word-groups and cannot be freely made up in speech (Veliyeva, 2014). They are always reproduced as ready-made units and are structurally stable. As a rule they possess stability of lexical components, and can be reproduced as single unchangeable collocations, such as:

red (blue, white, etc) flower

BUT red tape $\neq$ blue tape

red flower-red flowers

BUT red tape $\neq$ red tapes

When it comes to meaning, there exist two types of meaning of phraseological units: denotational and connotational.

Denotational meaning belongs to a whole phrase as a single inseparable unit, which means that the whole phrase (i.e., phraseological unit) expresses one definite meaning as in the following one.

apple sauce-nonsense (cəfangiyyat)

Connotational meaning belongs to the whole word-group.

old boy

According to Koonin, a stable word-group is characterized by a completely or partially transferred meaning (Koonin, 1981). Let's see the two criteria to distinguish free-word groups from phraseological units. They are the followings: a) semantic criterion, and b) structural criterion.

a) According to semantic criterion, first of all, in free word-groups each meaningful component stands for a separate concept.

a red flower, a pretty woman

Secondly, phraseological units convey a single concept.

red tape (= bureaucratism)

Phraseological units are characterized by different degrees of semantic change:

1). Semantic change may affect the whole word-group, which is referred as "complete transferred meaning".

to skate on thin ice (= to take risks-risk getmək), to have one's heart in one's boots (= to be anxious about something - nəya görasa narahat olmaq)

2). Semantic change may affect only one of the components of a word-group, which is called "partially 
transferred meaning".

to fall in love (aşıq olmaq), to have a small talk (əhəmiyyətsiz söhbət etmək)

b) According to structural criterion, the following two points are very important and should be taken into the consideration.

1). Restriction in substitution. In free word-groups components may be changed.

The cargo ship/vessel is carrying coal to Liverpool/Manchester

However, in phraseological units no word can be replaced without destroying the sense.

to carry coals to Newcastle

2). Introducing additional components. In free word-groups change can be made without affecting the general meaning.

The big ship is carrying a large cargo of coal to the port of Liverpool.

In phraseological units no additional components can be introduced.

the white elephant-NOT the big white elephant

In Modern English phraseological units have the following features, which make them different from free word-groups: They are the followings:

- semantic and structural stability;

- idiomacity (lack of motivation);

- ready-madeness;

- the most common structure: verb +object;

- formed from free word combinations.

\subsection{European Scholars' Viewpoints on Some Terms Connected with Phrases and Idioms}

Though phraseology was widely developed in post-Soviet country, foreign — especially European specialists also dealt with it. As the first book, where the word Phraseology was used, is considered the book by Sattler called Teutsche Ortographey und Phraseology from the 17th century, namely from the year 1607. Here the word Phraseology was here understood as a collection of synonyms.

Leonhard Lipka in 1974 can be considered as the first Englishman who dealt with this discipline. Phraseology has been developing in all of the Western European countries since then. Modern European linguists have founded the European Society of Phraseology.

The definition of Phraseology was given by different European scholars and it differs from an author to an author. In A Dictionary of English Idioms by Henderson (Henderson, 1947) Phraseology is defined as a very young linguistic discipline that deals with collocations (phraseologisms, similes $=$ comparisons, figurative phrases, phrasal verbs, multi-word units and idioms).

Harald Burger's definition of an idiom can be paraphrased as follows. "The meaning of an idiom does not appear on the surface, it is not clear at the first sight. One can find out what exactly an idiom means on grounds of further knowledge of the expression itself or of the context in which the idiom is used. The idiomatic phrase could be based on an external alikeness, such as for example in play cat and mouse with somebody. It is not difficult to imagine a cat playing with a mouse, so it is not difficult to guess the real meaning of such a phrase. On the other hand, there are idioms with in practice no alikeness with its real meaning, as an example of this feature can constitute an idiom to rain cats and dogs".

Cowie (1990) divides in his work Oxford Dictionary of Current Idiomatic English idioms into two groups:

a) Idioms: “... idioms, such as fill the bill or spill the beans do not mean what they appear to mean. The sense of the whole cannot be arrived at from a prior understanding of the parts. In the examples, a special meaning is attached to the whole expression."

b) Semi-idioms: “... one word may have a common, literal meaning, while the other has a specialized sense which may be difficult to grasp. Examples: foot the bill, sink one's differences (where in both cases the first word has a figurative meaning)".

Hornby's definition of an idiom is: "an idiom is a phrase whose meaning is difficult or sometimes impossible to guess by looking at the meanings of the individual words it contains." 
The author Jon Wright characterizes in his publication Idioms Organizer (Wright, 1999) idiom as an expression with following features:

a) It is fixed and is recognized by native speakers. You cannot make up your own!

b) It uses language in a non-literal-metaphorical way.

c) An idiom is a whole expression that usually cannot change, such as two heads are better than one. Sometimes the tense and the pronouns are changeable: I'm/she's/we were all at sixes and sevens.

In Lionel's (1991) Výkladový anglicko-český slovník s českými ekvivalenty a following definition of an idiom can be found:

- an expression with a meaning that cannot be guessed from the meanings of the individual words;

- The expressions of a language in general".

Idioms are, according to Báčová's thesis (2006), characteristic by:

Non-compositionality, which means that the meaning of the phrase is not a straightforward composition of the meaning of its parts. As an example can serve the idiom kick the bucket (to die), which does not have anything in common with the activity one imagines when heard the idiom (kicking into a bucket)

Non-substitutability, which means that the words of a collocation cannot be substituted by any words related to them. To illustrate this statement we can use the aforementioned idiomatic phrase kick the bucket. We cannot substitute for example the word bucket by the word scuttle, even if this expression is synonymous to the word bucket. If we do so, the idiomatical phrase loses its idiomaticity and does not mean to die any more.

Non-modifiability, which means that it is not possible to modify a collocation or to apply syntactic transfor-mations. If we say for example Jack kicked the yellow bucket or the bucket was kicked by a child, the phrase does not have the meaning to die any more. However there are some possibilities of modification of this phrase with the maintenance of the idiomatical meaning, such as Jack kicked his bucket or Jack's bucket was kicked.

Idiom "implies that the essential feature of the linguistic units is idiomaticity or lack of motivation". This opinion belongs to English and American linguists

\subsection{Approaches to the Study of Phraseological Units}

Besides the above-mentioned features of phraseological units, there are some approaches to the study of phraseological units, such as:

- semantic approach;

- functional approach;

- contextual approach.

Semantic approach determines that phraseological units are non-motivated (idiomacity), and also they are opposed to free-word combinations which are completely motivated.

Functional approach shows that phraseological units are specific word-groups functioning like word-equivalents. Like words they possess structural and semantic inseparability.

Contextual approach describes the fact that phraseological units are used in specific contexts - non-variable, or "fixed". By the way, non-variability is a stability of the lexical components within the semantic structure.

It should also be noted that there is variety of classifications of phraseological units, which will be described below.

\subsubsection{Classifications Based on a Semantic Approach}

This type of approach includes the followings:

a) semantic classification - according to the degree of motivation, which was put forward by Vinogradov (1986). According toVinogradov's classification, phraseological units are divided into the followings:

1). Phraseological combinations - word-groups with partially changed meaning.

to be good at smth., to have a bite, bosom friends

2). Phraseological unities - word-groups with completely changed meaning, the meaning of the unit does not correspond to the meanings of its constituent parts, but deducible as it is based on metaphor. 
to lock the stable door after the horse is stolen ("to take precautions too late").

a fish out of water ("a person situated uncomfortably outside its usual environment").

3). Phraseological fusions - word-groups with completely changed meaning; their meaning cannot be deduced from the meanings of its constituent parts.

at sixes and sevens ("in confusion or in disagreement")

to set one's cap at smb. ("to try and attract smb".)

b) structural classification - based on the ability to perform the same syntactical functions as words. This classification of R.Ginzburg differs from the one described above partially (Ginzburg, 1979). So, he divided the phraseological units into three groups, too.

1). Phraseological fusions - completely non-motivated word-groups, characterized by the complete stability of the lexical components and the grammatical structure.

to kick the bucket, red tape

2). Phraseological unities - partially non-motivated, the meaning is perceived through the metaphoric meaning of the unit, characterized by high degree of stability of the lexical components.

to show one's teeth, to wash one's dirty linen in the public

3). Phraseological collocations-motivated word-groups, have specific lexical valency which results in their stability

to take a liking/fancy, to bear a grudge/ malice

Ginzburg also classified phraseological units according to structure. Respectively, they are the followings:

1). verbal phraseological units which are verb equivalents.

to catch at a straw

2). substantive phraseological units which are noun equivalents.

dog's life

3). adjectival phraseological units which are adjective equivalents.

safe and sound

4). adverbial phraseological units which are adverb equivalents.

in the twinkle of an eye

5). interjectional phraseological units which are used like interjections.

Goodness gracious! Dear me!

c) structural-semantic classification by Smirnitsky. He tried to combine structural and semantic principles. Besides, he compared phraseological units with words. He divided phraseological units into the following ones:

i) one-summit (or one-top) units (Smirnitsky, 1998). Compared with affixed words, they have one meaningful constituent. One-summit units have the following varieties:

1). verbal-adverbial units which are equivalent to verbs in which grammatical and semantic centers coincide in the first component.

to back up - dastəklamək

to nose out-öyranib bilmək (araşdırmaq)

2). units equivalent to verbs in which semantic centre is in the second element and grammatical centre is in the first element.

to be tired

3). prepositional-nominal units-equivalent to unchangeable words: prepositions, conjunctions, adverbs. Semantic center is in the nominal constituent, there is no grammatical center

in the course of - during, on the nose-exactly

ii) two-summit (or two-top) units. Compared with compound words, they have two or more meaningful constituents. They have the following division: 
1). attributive-nominal units which are equivalent to nouns.

millstone round one's neck-boynunda ă̆ır yük

high road-şosse

2). verbal-nominal units which are equivalent to verbs.

to read between the lines - gizli monanı anlamaq

to speak BBC - düzgün ingilis dilində danışmaq

3). phraseological repetitions which are equivalents of adverbs or adjectives, components are joined by a conjunction.

back and forth-dala-qabăga

ups and downs—qalabə va məğlubiyyat

iii) multi-summit units which consist of a lot of meaningful elements.

to be a shadow of one's own self-özüna güvanmək

4.3.2 Classification Based on a Functional Approach

It consists of structural-semantic classification described by Koonin (1996).

Koonin's Classification is based on structural-semantic principle and also on the functions units fulfill in communication. According to his viewpoint, phraseological units can be:

1). nominative phraseological units.

a bull in a china shop

2). interjectional phraseological units.

a pretty kettle of fish!

3). nominative-communicative phraseological units - verbal word-groups which are transformed into a sentence when the verb is used in the Passive Voice.

to break the ice - the ice is broken

4). communicative phraseological units - proverbs and sayings.

spare a rod and spoil a child-uşă̆ arköyün böyütmək

Koonin, classifying phraseological units according to the structure denoted that they can be changeable/unchangeable. It means that they may:

1). have synonyms

$$
\text { to lift a finger-not to raise a finger }
$$

2). be used with a variable pronoun.

$$
\text { to pull one's leg }
$$

3). be used with both types of variability.

to give smb a piece/ a bit of one's mind

\subsubsection{Classification Based on a Contextual Approach}

This approach was put forward by Amosova (1989). She divided them into three groups:

1). Phraseological units which are units of a fixed context. She explains that fixed context is specific and unchanging sequence of lexical components and specific relations between them.

2). Phrasemes which are always binary, one component has a phraseologically bound meaning, the other serves as a determining context

small talk, small hours

3). idioms which are the new meaning created by the whole; here every element may have its original meaning weakened or completely lost.

$$
\text { in the nick of the time- "at the exact moment" }
$$

Idioms can be movable (changeable)/immovable. 
apple sauce/ the apple of one's eye

Idioms include:

1). Proverbs, which have the following features:

- They sum up the collective wisdom of the community, a popular truth or a moral lesson in a concise and imaginative way.

- They are metaphorical.

- They moralize.

Hell is paved with good intentions

- They admonish.

If you sing before breakfast, you will cry before night

- They criticize.

Everyone calls his own geese swans

- They give advice.

Don't judge a tree by its bark

- Their lexical components are stable.

- Their meaning is figurative.

- They are ready-made units.

- They are easily transformed into phraseological units.

Don't cast pearls before swine - to cast pearls before swine

2). Sayings:

- They are non-metaphorical, not figurative.

- Grammatically they are finished or completed sentences.

Where there is a way, there is a will

3). Familiar Quotations.

- They come from literature.

- In contrast to proverbs, they do not express finished judgment.

To err is human.

\section{Summary and Concluding Remarks}

In conclusion, it should be noted that phraseology includes all the combinations of two or more words functioning as a single unit, excluding free word combinations. It is a very interesting and at the same time young part of linguistics. However many linguists investigated it and tried to approach to it differently, there are some problems which remain unsolved now. In the article, we discussed the classification of phraseological units basing on semantic, functional and contextual approaches.

\section{References}

Akhmanova, M. O. (1972). Lexicology. Theory and Method. Moscow: Visshaya Shkola.

Amosova, N. N. (1989). Basics of English Phraseology (p. 97). Leningrad: Prosveshenie.

Arnold, I. V. (1959). Lexicology of Modern English language (p. 351). Moscow: Publishing House of Literature in Foreign Language.

Báčová, V. (2006). Thesis on Phraseology. Published in Chezk Republic.

Cowie, P. A. (1990). Oxford Dictionary of Current Idiomatic English. Oxford: Oxford University Press.

Ginzburg, R. A. (1979). A course in Modern English Lexicology (p. 269). Moscow: Visshaya Shkola.

Henderson, B. L. K. (1947). A Dictionary of English Idioms (vol. 2). J. Blackwood.

Koonin, A. V. (1981). English Phraseology. Theoretical Course (p. 285). Moscow: Science.

Koonin, A. V. (1996). Phraseology of Modern English Language (p. 380). Moscow: International relations. 
Lionel, S. (1991). Výkladový anglicko-český slovník s českými ekvivalenty, p. 268.

Shanskiy, N. M. (1957). Lexics and Phraseology of Modern Russian Language. Manual for part-time students (p. 168). Moscow: Uchpedgiz.

Smirnitsky, A. I. (1998). Lexicology of the English Language (p. 260). Moscow: MSU.

Veliyeva, N. Ch. (2014). Communicative-Pragmatic Paradigm of English Lexicology (p. 288). Baku: Science and Education.

Vinogradov, V. V. (1986). On the main types of phraseological units in the Russian language (p. 182). Moscow: Science.

Wright, J. (1999). Idioms Organizer. Heinle ELT, p. 296.

\section{Copyrights}

Copyright for this article is retained by the author(s), with first publication rights granted to the journal.

This is an open-access article distributed under the terms and conditions of the Creative Commons Attribution license (http://creativecommons.org/licenses/by/3.0/). 